\title{
Determinants of Market Value (Case of Jordanian Banks)
}

\author{
Farouq Altahtamouni $^{1}$ \\ ${ }^{1}$ Administrative \& Financial Sciences Department, Community College in Dammam, Imam Abdulrahman Bin \\ Faisal University, Saudi Arabia \\ Correspondence: Farouq Altahtamouni, Administrative \& Financial Sciences Department, Community College in \\ Dammam, Imam Abdulrahman Bin Faisal University, Saudi Arabia. \\ Received: August 23, 2017 \\ doi:10.5539/ibr.v11n1p124 \\ Accepted: December 5, 2017 \\ Online Published: December 19, 2017 \\ URL: https://doi.org/10.5539/ibr.v11n1p124
}

\begin{abstract}
This study aimed to find the best model to predict the market value of the Jordanian banks for the period from 2004 to 2013. Based on previous studies we have used investment, financing and dividend decisions in addition to profitability, size and growth to predict the market value which has been measured at market value of the shares to the book value, which is called by Tobin's Q.

By using the simple regression analysis it was reached to a statistical significance effect for each investment decision, profitability, size and expected growth on market value, and it was found out the absence of an effect for each of financing and dividends decisions on market value. And by Using multiple linear regression test and stepwise regression method in order to find out the best models to predict market value, the profitability, investment decision and expected growth are considered the best variables to predict market value whereas it explain $45 \%$ of changes in market value.
\end{abstract}

Keywords: Tobin's Q, Stepwise Regression, financial decisions, profitability

\section{Introduction}

The study of market value of corporation obtained considerable attention from the researchers as it had an attention in the literature of finance, the researchers agreed on maximizing the market value is the ultimate goal for the financial management that eclipsing the maximizing profit goal as a fundamental goal that corporations work to achieve.

The financial decisions must be taken under the light of achieving a goal that the corporations' administration seeks to achieve continuously which is developing and distributing available resources efficiency on the long run in order to maximize the corporation value and thus maximizing of shareholder wealth , and because of that corporations must set up their resolutions under the following standard : What is the effect of financing and investing decisions that are taken to increase the company's value as a whole and in a way leads to the survival, prosperity and growth of the corporation? (Haddad, 2009).

Whereas the investors in the financial markets looking forward to the market value which represent in the market return for the financial securities as part of their realized return in addition to dividends that some other investors looking forward, then the market value was considered according to the previous studies one of corporations' value forms, thus to the outstanding stocks for that corporations.

The market value of stocks is the cash value paid by the investor at any specific period of time, which determines by supply and demand forces in the financial market, but the other forms for stocks' value are: (Altamimi \& Salam, 2004)

1- Nominal value: The stabilized value in stock certificate which the establishment contract focuses on.

2- Book value: The stabilized value in company's records, and represent by per stock's share of owner's equity, and it relies in its account on financial reports.

3- Fair value: The value determine or justify financial and economic facts reflects with the corporation assets' value and growth averages in profits.

The studies continued since both (Modigliani \& Miller, 1958) studied how much the market value of corporations was affected by financing and investing decisions that worked on to find out which of these factors 
affecting the market value of corporations in order to be taken into consideration for investors as a determinant factor of investment.

According to the previous studies the market value are affected by fundamental elements represented in financial decisions which are the financing decision, investment decision, dividends decision and accounting profits, whereas the study of (Modigliani \& Miller, 1963) is consider one of the studies that was proved through it that the market value affected by the financing and investing decisions and the corporation's value increases if it is funded throughout the debt and it is because of the paid interest on debt will reduce taxes paid on income, thus the disposable income for investors will increase compared with no taxes, and this study came after both (Modigliani \& Miller 1958) introduced a study which dealt with searching in capital structure and its cost and the investment theory which found out that the corporation's value does not affected by the debt in capital structure, through assuming the existence of highly efficient markets, and no taxes on the corporation or personal taxes, and the data is available for everyone whether in corporations or individual investors, and also the interest in fixed regardless of the used debt ratio, and there are no prospects of bankruptcy.

Many researchers disagree on the effect of dividends' policy on market value and how much it affects on the market value, and (Godon,1959) sees that dividends work on increasing market value, and others see that market value does not affected by dividends' policy such as (M\&M,1961).

The study of (Ball \& Brown, 1968) was one of the first studies on accounting profits effect on market value, and (Rappaport, 1987) sees that accounting profits one of the most important determinants of market value, so the accounting profits are the result of decisions that are made in corporations' administrations, and those profits reflect in financial policies that will be continued for years ahead.

This study came out to continue the previous studies and to show what are influencing factors in calculated market value for Jordanian Banks in order to be function in calculating the market value for Jordanian investors in Bank Sectors which considered the higher market value among operating sectors in Jordanian market throughout years of study, and as described in table (1) whereas it shows the price index weighted by market value for operating sectors in Amman's stock exchange for securities.

Table 1. Price Index Weighted by Market Capitalization (point)

\begin{tabular}{llllll}
\hline Period & Banks & Insurance & Services & Industry & General \\
\hline 2004 & 7230.9 & 3726.9 & 1874.4 & 2526.9 & 4245.6 \\
2005 & 16892 & 7382.4 & 3332.5 & 2903.4 & 8191.5 \\
2006 & 10704.7 & 4156.3 & 2286.6 & 2507.6 & 5518.1 \\
2007 & 13886.7 & 4900.4 & 2740.3 & 4565.5 & 7519.3 \\
2008 & 11380.1 & 3821.3 & 1865.6 & 4560.1 & 6243.1 \\
2009 & 9368 & 3943.6 & 1700.6 & 4563.2 & 5520.1 \\
2010 & 8848.3 & 2103.5 & 1506.4 & 4841.7 & 5318 \\
2011 & 7542.3 & 1703.7 & 1302.1 & 4427.4 & 4648.4 \\
2012 & $7,297.40$ & $1,251.00$ & $1,240.40$ & $4,606.40$ & $4,593.90$ \\
2013 & $8,035.19$ & $1,214.13$ & $1,255.08$ & $3,210.42$ & $4,336.71$ \\
\hline
\end{tabular}

Source: Amman Stock Exchange web site.

This study was done by dealing with the most important market value's measures which is the market value to the book value, where this index were done by James Tobin (Tobin, 1969), (Tobin \& Brainard, 1977), and that index was done in order to calculate the market value to the replacement cost, but it was developed to calculate the market value of corporations throughout the following equation:

Tobin's q= Market value to Book value =

Market value of share

Book Value of Share

This measure is consider an index for corporation's ability to create the wealth for stocks' owners according to its historical cost, so the corporation that has ratio more than one is a successful in creating wealth, and the opposite gives an index of the wealth weakness (Alnaimi \& Altamimi, 2009), and it also gives an index if the corporation's stocks valued more of their value or undervalued.

(Haddad, 2009) has pointed out that corporations achieve high average for the return on the assets or on the equity then its market value is comparatively higher than its book value compared with corporations of low average for the return on their assets.

This measure is consider one of the most important measures of the market value in the study of (Altahtamouni \& Alslehat, 2014), so they proved throughout their study which conducted on Jordanian Banks that this measure of 
market value is most affected with accounting profits' measures among many measures for the market value, and we will see that it also was affected with other factors such as financial decisions.

\section{Objectives of the Study}

This study aims to know:

1- The effect of investment decision on market value.

2- The effect of financing decision on market value.

3- The effect of dividends decision on market value.

4- The effect of profitability on market value.

5- The effect of corporation's size on market value.

6- The effect of growth on market value.

7- Reaching the best models to predict the market value.

\section{The Importance of the Study}

The importance of this study from came from the attention of researchers and investors in the market value and to investigate the more factors that affect the market value. And the importance of study rises from that it is the first study (according to the researcher's science) which we can study the determinants of Tobin's Q throughout the application on operating banks in Jordanian Banks Sector, and its importance also rises from that we will work on finding the best models that thorough it we can predict the market value.

\section{The Study Problem}

We can formulate the study problem through the following questions:

1- Does the financial decisions (Investment, financing and dividends) affect on the market value?

2- Does the profitability affect on the market value?

3- Does the corporation's size effect on the market value?

4- Does the expected growth affect on the market value?

\section{Literature Review}

These are so many studies worked on studying determinants of the market value from various aspects using several measures for market value, and we can review some studies related to this one and related to some other variables were used.

(El-Kouri, Almwlla, 1997) studied the effect of dividends' policy on market value, where they found out an absence of a relationship between distributed profits and corporation's value.

Both researchers (Ben Naceur \& Goaied, 2002) tried in a study to find out the most important determinants of market value in Tunisia. They reached to an existing of a statistical significance positive relationship between dividends and market to book value, and a statistical significance positive relationship between profitability measured by the return on the assets and market value.

(Kaifeng, 2002) studied the relationship between capital structure measured by debts ratio and market value measured by market to the book value for corporation's stocks in Netherlands, and throughout conducting the regression test he came out to an existing of statistical significance positive relationship between capital structure and corporation's value for low- growth corporations, but for high- growth corporations the study did not find any relationship between capital structure and the corporation's value.

(Abbad, 2004) tried throughout a study to show the effect of capital structure represented in debt ratio on market value measured by the market to book value for stocks, and it has been shown the existing of statistical significance positive effect for debt on the market value.

(Bani Saeed, 2004) studied the effect of dividend policy, the stock return and debt ratio on the market value in Jordan and he came out to the existing of statistical significance effect for each of stock return and debt ratio on the market value, and he did not find an effect for dividends policy on the market value and that was on the levels of market and bank sectors.

In the study of (Ben Naceur \& Goaied, 2004) both researchers worked on studying the effect of each of the return, book value, dividends, debt and investment on the market value, and they reached to the existing of an effect for each of the return, book value and dividends on the market value, and there is no effect for each of 
debt and investment on the market value.

The study of (Pandey, 2005) aimed to find out which of the factors that affect on the market to the book value for stocks, and the researcher found out that each of the profitability and debt's ratio has a statically significance positive effect on the market value, and he also find out that each of the growth and size affect inversely on the market value.

(Asogwa, 2009) worked on to find out which factors determine the market value for bank in Nigeria. He found out that dividends policy are the most factors determine the market value represented in market to the book value for stocks than growth and profitability, and it has been shown the absence of an effect for each of the debt and size on the market value.

In studying the relationship between accounting profits and market value, both (Altahtamouni \& Alslehat, 2014) studied the relation between some accounting indicators and growth and several measures for market value including the market value measure to the book value for stocks throughout the application on the Jordanian banks. They found out to the existing of a relationship between accounting indexes and the market value to the book value, and that measure was one of the most affecting by accounting indexes from all the market value's measures.

\section{Research Methodology}

\subsection{Sample and Data}

The study society consists of Jordanian bank sector from the year of 2004 until 2013. The study sample has been chosen from all banks consisted for the Jordanian bank sector without exception subject to availability of data throughout the study period.

\subsection{The Study Hypotheses}

Hypotheses of the study have been formulated according to the questions of the study and their goals in order to test the relations between the study variables.

(H01): There is no statistically significant effect of investment decision on the market value for Jordanian banks.

(H02): There is no statistically significant effect of financing decision on the market value for Jordanian banks.

(H03): There is no statistically significant effect of dividend de cision on the market value for Jordanian banks.

(H04): There is no statistically significant effect of profitability on the market value for Jordanian banks.

(H05): There is no statistically significant effect of corporation's size on the market value for Jordanian banks.

(H06): There is no statistically significant effect of expected growth on the market value for Jordanian banks.

(H07): There is no statistically significant effect of financial decisions, profitability, corporation's size and expected growth on the market value for Jordanian banks.

\subsection{The Study Variables}

The following variables will be used in order to serve the study purposes:

\subsubsection{Independent Variables}

\section{1- Investment decision}

It has been measured by growth ratio in assets amount, which is representing the company's investment =

Assets amount per day $(\mathrm{t})$ - Assets amount per day ( $\mathrm{t}-1)$

Assets amount per day (t-1)

\section{2- Financing decision}

It has been measured by debt to equity ratio $=$ Total Liabilities

$$
\text { Total Assets }
$$

3- Dividend decision

It has been measured throughout the following equation:

Dividends per share

Earnings per share 
4- Profitability, according to the previous studies and determining the market to book value model, it was necessary to use the return rate on capital resources as a profitability measure, but according on the study of (Altahtamouni \& Alslehat, 2014) which they found out through it that the best profitability measures affecting in the market value is the earning per share.

Earnings per share $(\mathrm{EPS})=$ Net Income attributable to ordinary shareholders

$$
\text { Number of ordinary shares }
$$

5- Corporation's size, where it has been measured by the natural logarithm for total assets.

6- Expected growth, and it has been measured by the following equation:

Expected growth $=$ Return on equity $\times$ retention ratio

\subsubsection{Dependent Variable}

The market value hat has been measured by Tobin's Q.

Tobin's $\mathrm{Q}=$ Market value to book value for shares $=\underline{\text { Market value per share }}$

Book value per share

\subsection{Statistical Methods Used}

Two major tests will be used in this study for testing the relations according to the study hypotheses in addition to correlation test between the study variables and they are as follow:

1- Simple linear regression test using method of ordinary least squares (OLS).

2- Multiple linear regression test using stepwise regression in order to reach the best model to predict the market value throughout the mechanism of excluding the non-influential factors in the market value.

\subsection{The Study Models}

The following models were used in order to express the relationship between independent variables and dependent variable in this study:

- Simple linear regression

$\mathrm{TQ}=\mathrm{a}+\mathrm{b} \mathrm{I}+\mathrm{ei}$

Where is:

TQ: The market value measured by market value to the book value

I: Investment decision

$\mathrm{TQ}=\mathrm{a}+\mathrm{bF}+\mathrm{ei}$

Where is:

F: Financing decision

$\mathrm{TQ}=\mathrm{a}+\mathrm{b} \mathrm{D}+\mathrm{ei}$

Where is:

D: Dividend decision

$\mathrm{TQ}=\mathrm{a}+\mathrm{b} \mathrm{P}+\mathrm{ei}$

Where is:

P: Profitability

$\mathrm{TQ}=\mathrm{a}+\mathrm{bS}+\mathrm{ei}$

Where is:

S: Corporation size

$\mathrm{TQ}=\mathrm{a}+\mathrm{b} \mathrm{G}+\mathrm{ei}$

Where is:

G: Expected growth

- Stepwise multiple regression model

$\mathrm{TQ}=\mathrm{a}+\mathrm{b} 1 \mathrm{I}+\mathrm{b} 2 \mathrm{~F}+\mathrm{b} 3 \mathrm{D}+\mathrm{b} 4 \mathrm{P}+\mathrm{b} 5 \mathrm{~S}+\mathrm{b} 6 \mathrm{G}+\mathrm{ei}$ 


\section{Results of the Study's Tests}

\subsection{Results of the Descriptive Statistics}

By looking to table 2 we can find that the descriptive statistics for the study variables which indicates to the maximum and minimum value for the variables in addition to the average and standard deviation.

The table shows that the arithmetic mean for market value equals (1.6814) and the standard de viation equals (.94636), and this shows that some banks moving away with its market value from the sector's average during period of the study. The results shows that some banks worked on making a wealth for its owners, where the maximum value for the market value equals (5.35), and from the other hand some banks worked on destroying the wealth of its owners and that was shown throughout the minimum value of the market value which is (-.46), and with regard of that value which is negative value as a result of the existing of carry-forward losses from previous years worked on achieving a negative book value.

Table 2. descriptive statistics

\begin{tabular}{lllll}
\hline Variable & Minimum & Maximum & Mean & Std. Deviation \\
\hline TQ & -.46 & 5.35 & 1.6814 & .94636 \\
I & -.55 & .93 & .1280 & .18354 \\
F & .17 & 1.31 & .8627 & .10660 \\
D & .00 & 1.23 & .2862 & .30911 \\
P & -.38 & 1.80 & .2095 & .23474 \\
S & 17.79 & 22.62 & 20.3574 & .98212 \\
G & -.25 & .39 & .0726 & .08318 \\
\hline
\end{tabular}

7.2 Results of Correlation Analysis

The results of correlation analysis in table (3) indicate to the existing of statistical significance relation between each of investment decision, profitability, size and expected growth from the independent variables and the market value, and the analysis results did not indicate to the existing of a relation between financing decision and market value, and dividend decision and the market value, and this indicates that dividend decision and the debt volume does not form any index for investors in bank sectors to affect on the market value.

Table 3. correlation analysis

\begin{tabular}{|c|c|c|c|c|c|c|c|}
\hline Variable & TQ & $\mathrm{I}$ & $\mathrm{F}$ & $\mathrm{D}$ & $\mathrm{P}$ & $\mathrm{S}$ & $\mathrm{G}$ \\
\hline $\mathrm{TQ}$ & 1 & $.352^{*}$ & -.014 & -.142 & $.636^{*}$ & $.237 *$ & $.473 *$ \\
\hline I & & 1 & $-.246^{*}$ & -.137 & $.249 *$ & .043 & .147 \\
\hline $\mathrm{F}$ & & & 1 & -.069 & -.049 & $.295^{*}$ & .125 \\
\hline D & & & & 1 & .030 & $.312^{*}$ & $-.290 *$ \\
\hline $\mathrm{P}$ & & & & & 1 & $.334^{*}$ & $.556^{*}$ \\
\hline S & & & & & & 1 & .118 \\
\hline $\mathrm{G}$ & & & & & & & 1 \\
\hline
\end{tabular}

\section{* Denotes $1 \%$ level of significance}

\subsection{Results of Regression Analysis}

\subsubsection{Results of Analyzing Simple Linear Regression}

Table 4 indicates to the results of analyzing simple linear regression for market value on each of the independent variables, and it also shows the study assumptions test. Whereas the results indicate the existing of statistical significance effect for each of investment decision, profitability, size and growth on the market value, and furthermore it indicate that the most variable explaining the change in market value is the profitability whereas it reached (.400) R-Square, and the results indicate that the financing decision does not affect in the market value and does not explain any variables in the market value, and the results also show that dividends decision does not affect on the market value. 
Table 4. Results of analyzing simple linear regression

\begin{tabular}{|c|c|c|c|}
\hline Variable & Equation results & & Hypothesis testing \\
\hline \multirow[t]{3}{*}{ I } & Constant & $1.449^{*}$ & \\
\hline & Coefficient & $1.817^{*}$ & H01: : Rejected \\
\hline & R-square & .124 & \\
\hline \multirow[t]{3}{*}{$\mathrm{F}$} & Constant & $1.790 *$ & \\
\hline & Coefficient & -.126 & H02: : Accepted \\
\hline & R-square & .000 & \\
\hline \multirow[t]{3}{*}{$\mathrm{D}$} & Constant & $1.805^{*}$ & \\
\hline & Coefficient & -.434 & H03: : Accepted \\
\hline & R-square & .020 & \\
\hline \multirow[t]{3}{*}{$\mathrm{P}$} & Constant & $1.143^{*}$ & \\
\hline & Coefficient & $2.570 *$ & H04: : Rejected \\
\hline & $\mathrm{R}$-square & .400 & \\
\hline \multirow[t]{3}{*}{$S$} & Constant & -2.965 & \\
\hline & Coefficient & $.228 *$ & H05: : Rejected \\
\hline & R-square & .056 & \\
\hline \multirow[t]{3}{*}{ G } & Constant & $1.279 *$ & \\
\hline & Coefficient & $5.440 *$ & H06: : Rejected \\
\hline & R-square & .224 & \\
\hline
\end{tabular}

* Denotes $1 \%$ level of significance

\subsubsection{Results of Multiple Linear Regression Using Stepwise Regression Method}

Table 5 indicates to results of multiple linear regression test of market value on independent variables.

Table 5. Results of multiple linear regression

\begin{tabular}{ccc}
\hline & Multiple Regression & $\begin{array}{c}\text { Collinearity Statistics } \\
\text { (VIF) }\end{array}$ \\
\hline Constant & -.569 & 1.181 \\
& & 1.305 \\
I-Coefficient & $.995^{*}$ & 1.358 \\
F-Coefficient & .087 & 1.819 \\
D-Coefficient & -.367 & 1.477 \\
P-Coefficient & $2.004^{*}$ & 1.749 \\
S-Coefficient & .080 & Hypothesis Testing \\
G-Coefficient & 1.422 & H06: : Rejected \\
P-Value & .000 & .454
\end{tabular}

\footnotetext{
* Denotes $1 \%$ level of significance
}

The results show an existing statistically significance effect for independent variables of the study model on the market value, whereas the value of the significance of the model (.000), and the model explain $45 \%$ of changes in the market value.

Results in table (6) of the stepwise regression indicate that the best model in which it can be predict through with market value throughout the study variables (After the excluding the least elements affecting the market value which has no statistical significance effect on the market value) is:

$\mathrm{MV}=.982+1.978 \mathrm{P}+1.061 \mathrm{I}+1.978 \mathrm{G}$

The results indicate that independent variables in the third stepwise regression model explain $45 \%$ of changes in the market value as the Adjusted R-Square value indicates.

The results also indicate to the absence of multicolliniarity between independent variables whereas variance inflationary factor (VIF) between (1) and (5) then that indicates the absence of multicolliniarity problem between independent variables. 
Table 6. Stepwise regression

\begin{tabular}{|c|c|c|}
\hline \multicolumn{3}{|c|}{ Stepwise Regression } \\
\hline (1) & & \\
\hline Constant & $1.143^{*}$ & \\
\hline P-Coefficient & $1.978^{*}$ & \\
\hline P-Value & .000 & \\
\hline Adjusted R-Square & .400 & \\
\hline \multicolumn{3}{|l|}{$\begin{array}{l}\text { Stepwise Regression } \\
\text { (2) }\end{array}$} \\
\hline Constant & $1.047^{*}$ & $\begin{array}{l}\text { Collinearity Statistics } \\
\text { (VIF) }\end{array}$ \\
\hline P-Coefficient & $2.362^{*}$ & 1.066 \\
\hline I-Coefficient & 1.065 & 1.066 \\
\hline P-Value & .000 & \\
\hline Adjusted R-Square & .436 & \\
\hline \multicolumn{3}{|l|}{$\begin{array}{l}\text { Stepwise Regression } \\
\text { (3) }\end{array}$} \\
\hline Constant & $.982 *$ & $\begin{array}{l}\text { Collinearity Statistics } \\
\text { (VIF) }\end{array}$ \\
\hline P-Coefficient & $1.978^{*}$ & 1.511 \\
\hline I- Coefficient & $1.061^{*}$ & 1.066 \\
\hline G- Coefficient & $1.978^{*}$ & 1.447 \\
\hline P- Value & .000 & \\
\hline Adjusted R-Square & .452 & \\
\hline
\end{tabular}

* Denotes $1 \%$ level of significance

\section{Conclusions}

After conducting the simple and multiple linear regression analysis and stepwise regression to examine the study hypotheses, the results of the study indicates to:

1- The existing of an effect for investment decision in Jordanian banks on their market value, whereas the growth in the bank's assets are taken into consideration to determine the market value by the inve stors, and that result differs from the result of the study of (Ben Naceur \& Goaied, 2004).

2- There is no effect for financing decision on market value, and this result agreed with the study of each of the (Ben Naceur \& Goaied, 2002), (Ben Naceur \& Goaied, 2004) and (Asogwa, 2009), and it differs with the study of (Kaifeng, 2002), (Abbad, 2003), (Bani Saeed, 2004) and (Pandey, 2005), and that result may be due to the nature of bank's work and relying banks on deposits makes of the financial leverage high in banks and thus the investors do not take into consideration the financing decision in determining the market value.

3- The absence of an effect for dividends decision on market value, and this indicates that investors have no interest in distributed profits and reflect it of the market value for Jordanian banks, and some investors prefer profits retention than distribute it in order to take an advantage of these money in funding future investment projects, and it's clear in the inverse relation between dividends and investment decision, and the effect of increasing investment on market value as mentioned before. This result agreed with what was mentioned in (El-kouri, Almwlla, 1997) and (Bani Saeed, 2004) studies, and it does not agree with the studies of (Ben Naceur \& Goaied, 2002), (Ben Naceur \& Goaied, 2004) and (Asogwa, 2009).

4- The existing of an effect for profitability on market value, and it confirms on the positive relationship between profitability and market value, and also confirms that investors are interested in reading realized profits and reflect those profits in the market value as a major determinant and explainer to many of changes in market value for their investors, and this result agree with (Ben Naceur \& Goaied, 2002), (Bani Saeed, 2004), (Ben Naceur \& Goaied, 2004), (Pandey, 2005) and (Altahtamouni \& Alslehat, 2014) studies and (Asogwa, 2009).

5- The existing of an effect for bank size on market value in accordance that the banks' assets volume form a guarantee for investors and it is a security and guarantee factor for their deposits, and this result differ with the study of (Ben Naceur \& Goaied, 2002) and (Pandey, 2005) and (Asogwa, 2009).

6- The existing of an effect for expected growth on market value in accordance that investors take into consideration the expected growth in banks' profits and their future investments and reflect it on the current value for their investments, and this result agree with the study of (Altahtamouni \& Alslehat, 2014) and (Asogwa, 2009), and does not agree with what was mentioned in the study of (Pandey, 2005).

7- The results of stepwise regression analysis shows that the best variables explaining the changes in market 
value in market value's predicting model is profitability, investment decision and expected growth whereas these variables explain $45 \%$ of changes in market value for Jordanian banks.

\section{References}

Abbad, M. (2004). The Impact of Capital Structure on the Profitability and the Value of the Firm: An Empirical Study on the Industrial Companies Listed in Amman Stock Exchange. Unpublished Master thesis, Yarmouk University, Jordan.

Alnaimi, A. T., \& Altamimi, A. F. (2009). Advanced Financial Management, Dar Yazouri , Amman - Jordan.

Altahtamouni, F., \& Alslehat, Z. (2014). The impact of accounting indicators and growth on the market value. International Journal of Academic Research in Accounting, Finance and Management Sciences, 4 (2), 9-18.

Altamimi, A. F., \& Salam, O. A. (2004). Investment in Financial Securities: Management and Analysis, First Edition, Almaserah house for publication and distribution, Amman- Jordan.

Asogwa, R. C. (2009). Measuring the Determinants of Value Creation for Publicly Listed Banks in Nigeria: A Random Effects Probit (REP) Model Analysis. Paper for Presentation at the 14th Annual Conference on Econometric Modelling for Africa, 8-10 July.

Ball, R., \& Brown, P. (1968). An Empirical Evaluation of Accounting Income Numbers. Journal of Accounting Research, Autumn, 159-178. https://doi.org/10.2307/2490232

Bani, S., \& Fadi, G. (2004). Impact of Dividend Policy on Share Prices of Companies Listed in Amman Bursa . Unpublished Master thesis, Yarmouk University, Jordan.

Ben, N. S., \& Goaied, M. (2002). The relationship between dividend policy, financial structure, profitability and firm value. Applied Financial Economics, 12, 843-849. https://doi.org/10.1080/09603100110049457

Ben, N., \& Goaied, M. (2004). The Value Relevance of Accounting and Financial Information: Panel Data Evidence. Applied Financial Economics, 14(17), 1219-1224. https://doi.org/10.1080/0960310042000203019

El-Kkouri, R., \& Almwlla, M. (1997). The Effective Dividends Changes on Security Prices: The Case of Jordanian Companies. Abhath Al-Yarmouk, 13(1), 87-94.

Gordon, M. (1959). Dividend, Earning and stock prices. Review of Economics and Statistics, 41, 99-105. https://doi.org/10.2307/1927792

Haddad, F. S. (2009). Financial Management, Second Edition, Dar Al-Hamed for publication, Amman - Jordan .

Kaifeng, C. (2002). The Influence of Capital Structure on Company Value with Different Growth Opportunities. paper for EFMA Annual Meeting.

Miller, M. H., \& Modigliani, F. (1961). Dividend Policy, Growth and valuation of shares. Journal of Business, October, 21-28. https://doi.org/10.1086/294442

Modigliani, F., \& Miller, M. (1963). Corporate Income Taxes and the Cost of Capital: Acorrection. American Economic Review, 53, 433-443.

Modigliani, F., \& Miller, M., (1958). The Cost of Capital, Corporate Finance, and the Theory of Investment. American Economic Review, XLVIII, 261-297.

Pandey, I. M. (2005). What Drives the Shareholder Value? Asian Academy of Management Journal of Accounting and Finance, 1, 105-120.

Rappaport, A. (1987). Linking competitive strategy and shareholder value analysis. Journal of Business Strategy, 7(4), 58-67. https://doi.org/10.1108/eb039176

Tobin, J. (1969). A General Equilibrium Approach To Monetary Theory. Journal of Money, Credit and Banking, 1(1) (Feb., 1969), 15-29. https://doi.org/10.2307/1991374

Tobin, J., \& Brainard, W. C. (1977). Asset Markets and the Cost of Capital. Economic progress, private values and public policy, Essays in honor of William Fellner, North-Holland Publ. Co, 235-262.

Website: Amman Stock Exchange: www.ase.com.jo

\section{Copyrights}

Copyright for this article is retained by the author(s), with first publication rights granted to the journal.

This is an open-access article distributed under the terms and conditions of the Creative Commons Attribution license (http://creativecommons.org/licenses/by/4.0/). 